\title{
ÔNUS DA PROVA NO PROCESSO DO TRABALHO DIANTE DOS REFLEXOS DO NOVO CPC NA PERSPECTIVA DO ESTADO DEMOCRÁTICO DE DIREITO
}

\author{
PROOF ON THE LABOR PROCESS BEFORE THE REFLECTIONS OF THE NEW \\ CPC IN THE PERSPECTIVE OF THE DEMOCRATIC STATE OF LAW
}

Graciane Rafisa Saliba ${ }^{1}$

Vitor Salino de Moura Eça²

\section{RESUMO}

O instituto da prova é vislumbrado como o sustentáculo dos processos judiciais trabalhistas, construídos sobre os princípios processuais que permeiam o ramo laboral, destacando-se o princípio da busca da verdade real e o ônus da prova. A convergência dos esforços das partes e do magistrado para o alcance de um resultado que proporcione a aplicação efetiva do direito depende do modus probatório operacionalizado no decorrer da instrução, na qual, diante do Estado Democrático do Direito, deve imperar o debate e a participação dos envolvidos, superando a conduta autocrática e solipsista do magistrado. Assim, a possibilidade de distribuição dinâmica do ônus da prova, trazida pelo Novo Código de Processo Civil, nos casos previstos em lei ou diante de peculiaridades da causa, tal como impossibilidade ou dificuldade excessiva a uma das partes para provar o alegado, traz ao Direito Processual do Trabalho, com sua aplicação supletiva e subsidiária,

\footnotetext{
1 Doutora em Direito Privado e Mestre em Direito Público pela PUC/Minas. MBA em Direito do Trabalho pela FGV, com extensão pela Ohio University, Estados Unidos, e em Derecho del Trabajo y Crisis Economica pela Universidad Castilla la Mancha, Espanha. Graduada em Direito pela UFMG. Coordenadora do curso de Direito e Professora na Universidade Santa Úrsula - RJ, Universidade de Itaúna e Faculdade de Pará de Minas. Professora de cursos de pós-graduação. Advogada. Bolsista na Academia de Direito Internacional de Haia, Holanda. Membro da ILA - International Law Association. E-mail: graciane@gracianesaliba.com.br

2 Pós-doutor em Direito Processual Comparado pela Universidad Castilla-La Mancha, na Espanha. Professor Adjunto IV da PUC-Minas (CAPES 6), lecionando nos cursos de mestrado e doutorado em Direito. Professor visitante em diversas universidades nacionais e estrangeiras. Professor conferencista na Escola Nacional de Magistratura do Trabalho - ENAMAT e na Escola Superior de Advocacia da Ordem dos Advogados do Brasil. Pesquisador junto ao Centro Europeo y Latinoamericano para el Diálogo Social - España. Membro efetivo, dentre outras, das seguintes sociedades: Academia Brasileira de Direito do Trabalho - ABDT; Asociación Iberoamericana de Derecho del Trabajo y de la Seguridad Social - AIDTSS; Asociación de Laboralistas - AAL; Equipo Federal del Trabajo - EFT; Escuela Judicial de América Latina - EJAL; Instituto Brasileiro de Direito Social Júnior- IBDSCJ; Instituto Latino-Americano de Derecho del Trabajo y de la Seguridad Social ILTRAS; Instituto Paraguayo de Derecho del Trabajo y Seguridad; e da Societé Internationale de Droit du Travail et de la Sécurité Sociale. E-mail: profvitorsalino@gmail.com
} 
uma participação efetiva e inclusiva das partes, destacando-se a ratificação da busca da verdade real no Estado Democrático de Direito.

Palavras-chave: Direito processual do trabalho; Ônus da prova; Estado democrático de direito; Busca da verdade real.

\section{ABSTRACT}

The institute of proof is seen as the basis of labor judicial processes, built on the procedural principles that permeate the labor field, highlighting the principle of the search for real truth and the burden of proof. The convergence of the efforts of the parties and the magistrate to reach a result that provides for the effective application of the law depends on the modus operative during the course of the investigation, in which, before the Democratic State of Law, debate and participation of the involved, overcoming the magistrate's autocratic and solipsistic conduct. Thus, the possibility of a dynamic distribution of the burden of proof, brought by the New Code of Civil Procedure, in the cases provided for by law or in the light of the peculiarities of the case, such as impossibility or excessive difficulty for one of the parties to prove what is alleged, With its supplementary and subsidiary application, an effective and inclusive participation of the parties, standing out the ratification of the search for the real truth in the Democratic State of Law.

Keywords: Procedural labor law; burden of proof; Democratic state; search for the real truth.

\section{INTRODUÇÃO}

As provas processuais possibilitam a realização dos direitos que the são inerentes. É através da participação das partes na formação do provimento judicial, com apresentação de provas que se realiza um grande passo no Estado Democrático de Direito.

$\mathrm{O}$ direito à prova constitui-se um direito fundamental que possibilita 0 alcance e formação de um processo democrático, e, especialmente na seara trabalhista, na qual a primazia da realidade sobre a forma ressurge no âmbito processual como a busca da verdade real. 
Dada a aplicação supletiva do Direito Processual Civil para o Direito Processual do Trabalho, eis que ressurge a utilização da dinâmica do ônus da prova, possibilidade trazida pela reforma daquele ramo diante da lei 13.105/2015, que resultou no novo Código de Processo Civil. Elencada como o cerne do processo, ou seja, a prova se ergue como um instituto que confere credibilidade às decisões judiciais, e que possibilita a formação e participação conjunta das partes, superando a figura do juiz solipsista que decidia isoladamente e conduzia o processo de maneira autocrática.

Debate-se, assim, além da aptidão para a prova, direito consagrado na aplicação dinâmica do ônus da prova, os limites e a importância da figura magistral e das partes na formação do processo sob a égide do Estado Democrático de Direito.

Para tanto, numa forma de discussão da inserção da aptidão para a prova e da dinâmica do ônus da prova, explicar-se-á a aplicação do Direito processual do civil para o Direito processual do trabalho, a principiologia que permeia a seara trabalhista no que tange ao ônus probatório, e, por fim, a fundamentalidade do direito à prova como meio de formação do provimento judicial.

\section{APLICAÇÃO SUBSIDIÁRIA E SUPLETIVA DO NOVO CÓDIGO DE PROCESSO CIVIL NO DIREITO PROCESSUAL DO TRABALHO}

O Direito processual do trabalho disciplina o exercício da jurisdição na seara trabalhista, fundado sobre princípio e regras próprios e disciplina na Consolidação das Leis do Trabalho (CLT). Apesar da peculiaridade, o próprio instrumento celetista prevê a utilização subsidiária do Direito processual comum, assim entendido o Direito processual civil, nos termos do art. 769 da $\mathrm{CLT}^{3}$, desde que haja omissão da lei trabalhista e compatibilidade com os preceitos dessa mesma lei.

\footnotetext{
${ }^{3}$ Art. 769, CLT - Nos casos omissos, o direito processual comum será fonte subsidiária do direito processual do trabalho, exceto naquilo em que for incompatível com as normas deste Título.
} 
Nesse sentido vislumbra-se uma aplicação subsidiária, reitera-se, pois, que a utilização decorre de omissão na legislação trabalhista, mas ambos os ramos decorrem de uma teoria geral do processo, com preceitos comuns, como ressalta Gustavo Filipe Barbosa Garcia:

O Direito Processual do Trabalho relaciona-se com o Direito Processual Civil, pois neste são disciplinados institutos essenciais, estudados pela própria Teoria Geral do Processo, como jurisdição, competência, ação, petição inicial, defesa, audiência, prova, sentença, recurso, processo e procedimento.

Acrescente-se que o Direito Processual Civil, com ênfase no Código de Processo Civil e em outras leis esparsas, é subsidiariamente aplicável ao processo do trabalho, quando ausentes normas específicas e existir a compatibilidade com os princípios deste (art. 769 da CLT). (GARCIA, 2017, p. 28)

Na fase de execução trabalhista utiliza-se, diante da omissão da CLT, a Lei de Execuções fiscais, lei 6.830/80, por força do art. 889 da CLT, e, após recorre-se ao Código de Processo Civil.

O novo Código de Processo Civil acrescentou, à subsidiariedade elencada na CLT, a possibilidade de uma aplicação supletiva do Direito processual civil ao Direito processual do trabalho, ao dispor, no art. 15, que, "na ausência de normas próprias que regulem os processos penais, eleitorais, administrativos ou trabalhistas e nos processos coletivos as disposições deste Código Ihes serão aplicadas supletiva e subsidiariamente".

Leonardo Tibo Barbosa Lima apresenta a distinção entre os termos subsidiário e supletivo:

De início, cumpre fazer distinção entre os termos subsidiário e supletivo, os quais, apesar de serem coloquialmente utilizados como sinônimos, não o são. Conforme consta da Emenda Parlamentar relativa ao citado artigo, constante do PL 8.046/10, a aplicação subsidiária "significa a integração da legislação subsidiária na legislação principal, de modo a preencher os claros e as lacunas da lei principal", ao passo que a supletiva ou complementar "ocorre quando uma lei completa a outra".

Em outras palavras, a aplicação subsidiária do CPC à CLT teria lugar quando esta fosse omissa (lacuna normativa), ao passo que a supletiva não dependeria da omissão, podendo ser aplicada conjuntamente (lacunas ontológicas e axiológicas). (LIMA, 2017, p. 36) 
O que se denota é que o legislador sinalizou a possibilidade de utilização da lei processual civil em situações além da omissão, mas com uma função suplementar, quando propiciar melhores condições para o hipossuficiente, num atendimento dos preceitos principiológicos do Direito processual do trabalho e do próprio Direito do trabalho. Leonardo Tibo Barbosa Lima ressalta a aplicabilidade supletiva:

Destarte, apesar de haver norma expressa na CLT, é possível cogitar da aplicação supletiva do CPC de 2015, quando o dispositivo importado for compatível com os princípios do processo trabalhista, v.g., para proteger o trabalhador hipossuficiente, simplificar as formas, tornar mais célere 0 processo e garantir mais efetividade à execução. (LIMA, 2017, p. 37)

Carlos Henrique Bezerra Leite explicita a heterointegração que seria plausível para suprimento das lacunas normativas, ontológicas e axiológicas, numa interpretação evolutiva, quando a norma trabalhista apresenta um envelhecimento, ou seja, com o surgimento de normas que incrementem a prestação jurisdicional justa e efetiva:

\begin{abstract}
A heterointegração pressupõe, portanto, existência não apenas das tradicionais lacunas normativas, mas, também, das lacunas ontológicas e axiológicas. Dito de outro modo, a heterointegração dos dois subsistemas (processo civil e trabalhista) pressupõe a interpretação evolutiva do art. 769 da CLT, para permitir a aplicação subsidiária do CPC não somente na hipótese (tradicional) de lacuna normativa do processo laboral, mas, também, quando a norma do processo trabalhista apresentar manifesto envelhecimento que, na prática, impede ou dificulta a prestação jurisdicional justa e efetiva deste processo especializado. (LEITE, 2017, p. 105)
\end{abstract}

A evolução proporcionada pelo Código de Processo Civil, ao trazer a supletividade, possibilita o atendimento aos fins teleológicos das próprias normas trabalhistas, quando a utilização pode ocorrer não apenas em caso de omissão, mas como meio de aprimoramento.

Assim, a supletividade advinda do CPC de 2015 não tem o condão de revogar os artigos 769 e 889 da CLT, persistindo os filtros de omissão e 
compatibilidade, entretanto, o requisito da omissão passou a abranger não somente as lacunas normativas, mas também as axiológicas e ontológicas, numa tentativa de aperfeiçoamento do Direito processual do trabalho para atendimento da finalidade buscada nesse ramo, a celeridade e a efetividade.

\title{
2 A PRINCIPIOLOGIA ÔNUS DA PROVA NO DIREITO PROCESSUAL DO TRABALHO
}

A consistência e todo o embasamento de um ordenamento jurídico advém dos princípios sobre o qual se organiza. São eles responsáveis pelo direcionamento, desde o criador das normas ao intérprete das mesmas.

Nesse sentido, Carlos Henrique Bezerra Leite explicita a necessidade de harmonização dos princípios, gerais ou específicos, para atendimento da finalidade do ramo:

\begin{abstract}
A harmonização do sistema ocorre porque os princípios especiais ou estão de acordo com os princípios gerais ou funcionam como exceção. Nessa ordem, as normas, regras, princípios especiais e princípios gerais seguem a mesma linha de raciocínio, com coerência lógica entre si.

Além da coerência lógica, deve haver uma coerência teleológica entre os princípios que compõem o sistema, consentânea com determinados fins políticos, filosóficos, éticos e sociológicos. Com isso, as normas assumem, no sistema, um caráter instrumental na busca de determinados valores idealizados pela sociedade. (LEITE, 2017, p. 54)
\end{abstract}

Os princípios exercem uma tríplice função, informativa, destinada ao legislador, com o intuito de indicar o tipo de norma que deve ser produzida em determinada seara; função interpretativa, que delimita a interpretação e a compreensão dos significados e sentidos das normas e proposições que compõem o sistema jurídico; e, ainda, a função normativa, que possibilita ao aplicador do direito a utilização dos princípios na solução de casos concretos, ou seja, na forma direta, e também na forma indireta, para integração do sistema nas hipóteses de lacuna.

A importância é dada não somente por exercerem papel integrador das diversas disposições legislativas trabalhistas, mas por indicar inclusive o sentido que 
deve ser dado à interpretação. Constata-se que não se pode interpretar qualquer artigo isoladamente, sem ter em mente os princípios que regem o sistema, pois é sobre eles que se erguem as normas, as quais, assim, devem ser vislumbradas a partir desses princípios, como enxergar através de um telescópio, o ângulo e alcance é dado por esse instrumento.

No tocante ao ônus da prova na seara trabalhista, dois princípios devem ser destacados para seu entendimento, o princípio da busca da verdade real e o próprio princípio do ônus da prova.

\subsection{PRINCÍPIO DA BUSCA DA VERDADE REAL}

A busca da verdade real é sustentada como princípio peculiar do Direito processual do trabalho, e pode ser vislumbrado como uma decorrência do princípio da primazia do direito sobre a forma, existente no campo do Direito material do trabalho. O prestígio à realidade se perfaz como um tributo à verdade.

A utilização da prova testemunhal, bem como a importância que representa na seara trabalhista, advém desse princípio, que indica a prevalência da realidade sobre documentos, ou seja, sobre a própria formalidade. A pretensão de se decidir conforme os acontecimentos reais, e não meramente os apresentados formalmente, mediante documentos, ganha relevo no direito processual do trabalho, haja vista a interação necessária com um cotidiano laboral baseado muito mais em contratos tácitos e verbais, assim como alterações informais, e não uma prevalência de contratos escritos e formais. O princípio material do qual parte a busca da verdade real, o princípio da primazia da realidade indica a importância do que realmente aconteceu, é apresentado por Vólia Bomfim como uma forma de proteção ao trabalhador:

O princípio da primazia da realidade destina-se a proteger o trabalhador, já que seu empregador poderia, com relativa facilidade, obrigá-lo a assinar documentos contrários aos fatos e aos seus interesses. Ante o estado de sujeição permanente que o empregado se encontra durante o contrato de 
trabalho, algumas vezes submete-se às ordens do empregador, mesmo que contra sua vontade. (CASSAR, 2014, p. 187)

O princípio da primazia da realidade sobre a forma é chamado por alguns autores, dentre eles Maurício Godinho Delgado, por contrato realidade, apesar da discordância de outros, como de Vólia Bomfim Cassar, que ressalta a diferença dos institutos, elencando a primazia da realidade como um princípio e o contrato realidade como uma teoria, com natureza jurídica distinta. O supramencionado autor assim descreve:

O princípio da primazia da realidade sobre a forma (chamado ainda de princípio do contrato realidade) amplia a noção civilista de que o operador jurídico, no exame das declarações volitivas, deve atentar mais à intenção dos agentes do que ao envoltório formal através de que transpareceu a vontade (art. 85, CCB/1916; art. 112, CCB/2002).

No Direito do trabalho deve-se pesquisar, preferentemente, a prática concreta efetivada ao longo da prestação de serviços, independentemente da vontade eventualmente manifestada pelas partes na respectiva relação jurídica. A prática habitual - na qualidade de uso - altera o contrato pactuado, gerando direito e obrigações novos às partes contratantes (respeitada a fronteira da inalterabilidade contratual lesiva).

Desse modo, o conteúdo do contrato não se circunscreve ao transposto no correspondente instrumento escrito, incorporando amplamente todos os matizes lançados pelo cotidiano da prestação de serviços. O princípio do contrato realidade autoriza, assim, por exemplo, a descaracterização de uma pactuada relação civil de prestação de serviços, desde que no cumprimento do contrato despontem, concretamente, todos os elementos fático-jurídicos da relação de emprego (trabalho por pessoa física, com pessoalidade, não eventualidade, onerosidade e sob subordinação). (DELGADO, 2016, p. 211)

Apesar da discordância da autora Vólia Bomfim Cassar sobre o contrato realidade como princípio, ela o elenca como uma teoria aplicável ao Direito do Trabalho, denotando a essencialidade de consideração da verdade, da própria realidade nessa seara, o que, então, é levado à formação do processo. Ao explicitar as teorias que explicam a teoria jurídica da relação de emprego, menciona a teoria eclética ou do contratualismo realista, e explica que foi chamada por Mario de La Cueva de contrato-realidade: 


\begin{abstract}
Uma variação da corrente contratualista é a teoria eclética ou do contratualismo realista, desenvolvida no México por Mário de La Cueva, com o nome de contrato-realidade. $\mathrm{O}$ autor advoga que a relação jurídica de trabalho se aperfeiçoa ou pela vontade das partes (contrato expresso) ou pelo fato (trabalho efetivo), ainda que não haja convenção (contrato tácito). (CASSAR, 2014, p. 237)
\end{abstract}

Assim, ainda que considerada como expressão de uma corrente, o enfoque demonstra que o direito do trabalho parte da própria realidade, que deve prevalecer sobre qualquer formalidade ou burocracia. Tal principiologia é refletida no Direito Processual do Trabalho como o princípio da busca da verdade real, o qual é essencial para que se alcance um processo realmente democrático e consoante com a realidade.

A prova testemunhal ganha força no processo trabalhista como meio de expressão dessa preponderância fática, e há destaque desse princípio inclusive em julgados, como se averigua no trecho: "PROVA TESTEMUNHAL. No Processo do Trabalho, vigora o princípio da primazia da realidade, que faz com que a prova documental ceda espaço à testemunhal, quando esta se mostra firme no sentido de desconstituição daquela." (RO 00599.401/98-2. TRT 4a região. 5a turma. Relator Francisco Rossal de Araújo. DJ 12.05.2003).

Apesar da utilização do termo no supramencionado trecho, na esfera processual o princípio da primazia da realidade é exposto, como já dito, como o princípio da busca da verdade real.

A prova testemunhal, diante desse contexto, se destaca como uma das principais, pois revela os acontecimentos do contrato, e demonstra o que de fato sucedeu no mundo laboral. $\mathrm{O}$ indeferimento de produção de prova testemunhal, ou seja, oral, pode levar inclusive ao cerceamento de defesa, acarretando a nulidade da sentença:

INDEFERIMENTO PRODUÇÃO DE PROVA ORAL. CERCEAMENTO DE DEFESA. NULIDADE DA SENTENÇA. Nos termos do art. 370 do $\mathrm{CPC} / 2015$, caberá ao juiz determinar as provas necessárias ao julgamento do mérito, sendo-lhe conferida a prerrogativa instrutória de indeferir, mediante decisão fundamentada, as diligências que considerar inúteis ou 
meramente protelatórias. No entanto, tal prerrogativa não é absoluta devendo respeitar os limites dos direitos fundamentais ao contraditório e à ampla defesa, e dos princípios da primazia da realidade e da busca pela verdade real. Porquanto, evidenciado o manifesto prejuízo à parte que se vê obstada de produzir prova essencial à comprovação dos fatos alegados, deve ser declarada nula a r. sentença por cerceamento de defesa, impondo-se o retorno dos autos à origem para realização de nova audiência de instrução e prolação de nova decisão. (Proc. n. 001042060.2015.5.03.0089 (AIRO). Relator Desembargador Marcelo Lamego Pertence. TRT $3^{a}$ região. $7^{a}$ turma. Publicado no DEJT/TRT3 em 20/10/2017)

A necessidade de alcance dos fatos para um decisão efetiva e coerente leva ao Direito Processual do Trabalho uma postura ativa do juiz, não figurando apenas como um espectador, mas importante figura na formação do processo com viés democrático. A sua atuação deve ser pautada na paridade de armas, possibilitando às partes, reconhecidas as peculiaridades e especificidades de cada uma, apresentar os fatos e debater dialogicamente. Esse é um meio de possibilitar que impere a verdade, sem deixar de atentar para uma dinâmica processual com participação das partes e oportunização de debates, para, então, alcançar a almejada verdade real.

\subsection{PRINCÍPIO DO ÔNUS DA PROVA}

O ônus probatório representa um encargo para a parte que, ao alegar o direito, deve demonstrar a plausibilidade com as provas admitidas em direito. A Consolidação das Leis do Trabalho se limitava a explicitar que quem alega deve provar, entretanto, num processo de reconhecimento da dificuldade das partes diante de situações em que o Código de Processo Civil, de 2015, já avançou ao expor, no art. 373 que o autor deve provar o direito constitutivo, e o réu a existência de fato impeditivo, modificativo ou extintivo do direito do autor, mas possibilitando que, nos casos previstos em lei, ou diante de peculiaridades possa aplicar um ônus dinâmico da prova, passando a obrigação a quem tenha maior facilidade de obtenção da prova, demonstra a evolução da causa probatória. A redação do artigo do Código de Processo Civil foi clara e inovadora: 
Art. 373. O ônus da prova incumbe:

I - ao autor, quanto ao fato constitutivo de seu direito:

II - ao réu, quanto à existência de fato impeditivo, modificativo ou extintivo do direito do autor.

$\S 1$ 을 casos previstos em lei ou diante de peculiaridades da causa relacionadas à impossibilidade ou à excessiva dificuldade de cumprir o encargo nos termos do caput ou à maior facilidade de obtenção da prova do fato contrário, poderá o juiz atribuir o ônus da prova de modo diverso, desde que o faça por decisão fundamentada, caso em que deverá dar à parte a oportunidade de se desincumbir do ônus que lhe foi atribuído.

$\S 2$ ㅇ A decisão prevista no $\S 1$ 을 deste artigo não pode gerar situação em que a desincumbência do encargo pela parte seja impossível ou excessivamente difícil.

§ 3o A distribuição diversa do ônus da prova também pode ocorrer por convenção das partes, salvo quando:

I - recair sobre direito indisponível da parte;

II - tornar excessivamente difícil a uma parte o exercício do direito.

§ 40 A convenção de que trata o § 3o pode ser celebrada antes ou durante o processo. (BRASIL, 2015)

O Código de Processo Civil trouxe à tona a reflexão para as peculiaridades e especificidades das partes no processo, uma formação democrática, na qual cada um deve participar conforme a possibilidade. Esse procedimento possibilita, além de uma aproximação das partes, proporciona um debate que enriquece e incrementa a decisão que será ali formada. Outros artigos do Código de Processo Civil explicitam o ônus da prova, a qual parte deve recair, tal como no art. 429:

Art. 429. Incumbe o ônus da prova quando:

I - se tratar de falsidade de documento ou de preenchimento abusivo, à parte que a arguir;

II - se tratar de impugnação da autenticidade, à parte que produziu o documento. (BRASIL, 2015)

A alegação de falsidade de documento, assim como a impugnação da autenticidade são especificadamente tratadas para que não restem dúvidas no momento da produção probatória, entretanto, casos esparsos podem surgir ao longo do debate processual, carecendo de posicionamento judicial, sempre guiado pelos princípios constitucionais da ampla defesa e contraditório, bem como pela necessidade de alcance da verdade real, coloca nas mãos do juiz a necessidade de 
delimitação das questões de fato sobre as quais as partes devem provar, ou seja, a condução processual democrática possibilita, a partir da discussão enfrentada no processo, que o juiz encarregue à parte mais capacitada para tal, a produção de determinada prova, como explicitado no art. 357 do Código de Processo Civil:

Art. 357. Não ocorrendo nenhuma das hipóteses deste Capítulo, deverá o juiz, em decisão de saneamento e de organização do processo:

I - resolver as questões processuais pendentes, se houver;

II - delimitar as questões de fato sobre as quais recairá a atividade probatória, especificando os meios de prova admitidos;

III - definir a distribuição do ônus da prova, observado o art. 373;

(...)(BRASIL, 2015)

Essa influência democrática levada ao Direito Processual Civil em 2015 foi reflexo dos princípios constitucionais que reafirmar a democracia com aplicação de um debate entre as partes e o juiz, numa relação coordenada e não meramente subordinada, possibilitando a maior interatividade para alcance da realidade fática, com contraditório e ampla defesa sendo aplicados. Diante dos argumentos e documentos levados a juízo, bem como dos depoimentos, possibilita-se a requisição de outros necessários para a formação da convicção do juiz, surgidos de próprio debate e interação das partes.

Assim, esse contexto, já aplicado ao processo do trabalho subsidiariamente, numa aplicação do art. 769 da Consolidação das Leis do Trabalho, e também supletivamente, com 0 art. 15 do Código de Processo Civil, levou também à modificação da própria redação do art. 818 da CLT, com a lei 13.467/2017, assim ficando:

Art. 818. O ônus da prova incumbe:

I - ao reclamante, quanto ao fato constitutivo de seu direito;

II - ao reclamado, quanto à existência de fato impeditivo, modificativo ou extintivo do direito do reclamante.

$\S 1$ o Nos casos previstos em lei ou diante de peculiaridades da causa relacionadas à impossibilidade ou à excessiva dificuldade de cumprir o encargo nos termos deste artigo ou à maior facilidade de obtenção da prova do fato contrário, poderá o juízo atribuir o ônus da prova de modo diverso, desde que o faça por decisão fundamentada, caso em que deverá dar à parte a oportunidade de se desincumbir do ônus que the foi atribuído. 
§ 2 o A decisão referida no $\S 1$ 으 deste artigo deverá ser proferida antes da abertura da instrução e, a requerimento da parte, implicará o adiamento da audiência e possibilitará provar os fatos por qualquer meio em direito admitido.

§ 3ㅇ A decisão referida no $\S 1$ 을 deste artigo não pode gerar situação em que a desincumbência do encargo pela parte seja impossível ou excessivamente difícil." (NR) (BRASIL, 2017)

Salienta-se que, na nova redação do próprio instrumento trabalhista, a CLT, a atribuição do ônus da prova de modo diverso do previsto na lei, pode ocorrer, desde que o juiz vislumbre a impossibilidade ou a excessiva dificuldade de cumprimento do encargo, mas, de toda forma, isso deve ocorrer por decisão fundamentada, com oportunização às partes de contraditório e também exercício da ampla defesa.

Há, assim, uma aplicação dos princípios constitucionais, a formação de um processo democrático, reconhecidas as especificidades das partes e dos fatos, para alcance, mediante de um debate de todos os envolvidos, de uma sentença que seja efetiva na solução do caso.

\section{DIREITO FUNDAMENTAL À PROVA E APTIDÃO PARA A PROVA NO ESTADO DEMOCRÁTICO DE DIREITO}

A aptidão para a prova, com uma distribuição dinâmica do ônus, trata-se na verdade da superação da regra do ônus da prova baseada meramente na incumbência de quem alega deve provar, que é superada por uma interpretação conjugada com os princípios constitucionais do acesso à justiça, contraditório, ampla defesa e igualdade substancial das partes, tendo em vista que, no decorrer da formação processual, em determinadas circunstâncias, uma das partes tem maior aptidão e facilidade, ainda que, a princípio, não detenha o ônus da prova, o que acarretará então a sua necessidade de prova, para levar a uma efetividade do direito.

Como ressalta Mauro Schiavi, "o presente princípio determina que deve produzir a prova não quem detenha o ônus processual, mas sim quem detenha 
melhores condições materiais ou técnicas para produzir a prova em juízo" (SCHIAVI, 2015, p. 657).

Ao considerar que a prova é um instrumento de demonstração da veracidade de uma proposição, vislumbra-se, num processo em que as partes e juiz participam conjuntamente, para uma formação participada e democrática, Bento Herculano Duarte salienta que a prova pode partir de qualquer um dos entes envolvidos:

\begin{abstract}
Enfim, a prova consiste no meio pelo qual se estabelece a existência ou a inexistência de um fato. $O$ sujeito que produz a prova tanto pode ser a parte como o juiz ou mesmo um terceiro. Prevalece, portanto, o caráter instrumental da prova, pelo que se acentua seu aspecto objetivo. Não obstante, o centro da prova é o poder de convencimento sobre o julgador, que é quem the avalia e aquilata, pelo que não se pode desprezar seu sentido subjetivo. (DUARTE, 2016, p. 70)
\end{abstract}

A conjugação dos princípios que norteiam a seara trabalhista, da primazia da realidade e da busca da verdade real, ratificam a necessidade de buscar todos os meios de prova possíveis para a efetividade da decisão judicial. E, ainda, o reconhecimento das peculiaridades de cada parte na formação do processo, as dificuldades e esforço excessivo, os obstáculos para que se consiga a obtenção de determinada prova que pode estar em poder da outra parte. Diante disso, Bento Herculano Duarte expõe a aplicação no processo trabalhista da inversão do ônus da prova:

Se não víamos o porquê de não aplicar a regra do CDC ao processo do trabalho, agora irrefutavelmente impõe-se que o magistrado trabalhista inverta o ônus da prova em favor do trabalhador, sempre que verificar sua peculiar dificuldade em desincumbir-se do ônus respectivo, e desde que se mostre acessível ao empregador. (DUARTE, 2016, p. 74)

Ressalta-se que a prova constitui direito fundamental das partes, que, inclusive, podem participar de todo o processo, como já reiterado, para uma formação dialógica participada, o processo é formado mediante a discussão e os debates das partes e do juiz, numa relação de coordenação e não subordinação. A 
atividade de julgamento não pode ser desenvolvida pelo juiz isoladamente, numa conduta autocrática e solipsista, mas deve ser participada, informativa, democrática. Cleber Lúcio de Almeida ressalta essa participação essencial de todos os envolvidos no processo democrático:

As partes são sujeitos do processo e da instrução, possuindo, portanto, o direito de participar de todas as fases do procedimento probatório. Essa é uma decorrência do direito ao devido processo legal, que é conformado, dentre outros, pelos princípios da ampla defesa, do contraditório e da publicidade. A participação das partes em todas as fases do procedimento probatório legitima o seu resultado e, com isso, a decisão com esteio nele proferida. (ALMEIDA, 2013, p. 100)

O que se vislumbra é não apenas a oportunidade de inversão do ônus da prova, como previsto no Código de Defesa do Consumidor, no art. $6^{\circ}$, VIII, mas possibilitar, mediante um debate com contraditório, das partes e do juiz, de apresentação das provas por aquele que detêm condição para tanto.

Não há um confronto com o texto trazido pelo art. 818 da CLT, inclusive modificado pela lei 13.467/2017, que corroborou o trazido pelo CPC de 2015, mas uma interpretação consoante com os princípios constitucionais democráticos da própria Constituição da República Federativa do Brasil de 1988.

O que se enfrenta, pois, é o debate da natureza da prova, que constitui um direito fundamental das partes, ou seja, no momento em que considera-se que "os direitos humanos e os direitos fundamentais têm como finalidade, que lhes é comum, criar e manter as condições necessárias para uma existência digna (ALMEIDA, 2013, p. 171), pode ser afirmado que a prova constitui um direito fundamental, pois a sua comprovação de veracidade que leva à satisfação de um direito proporciona o gozo de uma existência digna, ou seja, condições propícias para exercício da liberdade, em conformidade com os ditames legais.

O direito à prova constitui, assim, um direito humano constitucionalizado, ou seja, um direito fundamental, reconhecido de forma expressa na Constituição da República Federativa do Brasil de 1988, no art. 5, LV, que reconhece o direito aos meios inerentes à defesa, ou seja, é dado às partes o direito de se defender, 
provando. Cleber Lúcio de Almeida salienta a essencialidade do direito à prova como consequência do reconhecimento de um próprio direito:

De outro lado, o reconhecimento do direito à prova é uma consequência necessária do reconhecimento do direito: a) à dignidade humana, posto que esta somente se realiza no gozo pleno dos direitos que lhe são inerentes, para o qual contribui, no processo, a prova: b) de liberdade, vez que a prova constitui uma exigência e uma dimensão da liberdade das partes; c) de acesso à justiça, à ampla defesa, ao contraditório, ao processo justo, à não admissão da prova ilícita, à democracia processual, à justa solução dos conflitos submetidos ao Poder Judiciário, à efetividade da jurisdição e do processo e ao procedimento. (ALMEIDA, 2013, p. 174)

Nesse sentido, além de vislumbrar a prova como direito fundamental, possibilitando a apresentação da prova pela parte que detêm maior aptidão para fazê-la, para que, assim, efetivamente exista o direito à prova, é importante salientar que todos participam no processo democrático, partes e juiz, como explicado por Cleber Lúcio de Almeida:

Acrescente-se que estabelecer, como modelo, o processo democrático, é reconhecer o direito à prova, posto que no processo verdadeiramente democrático as partes têm o direito de participar da formação do provimento jurisdicional e uma das formas de fazê-lo é fornecer ao juiz os elementos necessários à formação de sua convicção sobre a ocorrência de tais fatos controversos. (ALMEIDA, 2013, p. 174)

O que se pretende explicitar é a importância da prova, e, dada sua fundamentalidade, tem que ser oportunizada a feitura da mesma pela parte que detém maior capacidade, e isso somente pode ser verificado se as partes e o juiz participam efetivamente na formação do provimento jurisdicional, ou seja, se o processo é construído com o diálogo e debate das partes e do juiz, sem posição autocrática do julgador, que se coloca muito mais como um facilitador do debate das partes, e consegue, assim, verificar a aptidão para a prova, e não necessariamente ocorre uma inversão do ônus da prova.

Como ressalta Mauro Schiavi, nessa atuação conjunta das partes e do juiz, diante dos rumos constitucionais do acesso à justiça, da efetividade da decisão, e da 
solução do processo em tempo razoável, é preciso que o juiz assuma não uma posição de mero espectador, e nem de inquisidor, mas uma posição ativa para proporcionar o debate das partes:

\begin{abstract}
De outro lado, não se trata o processo do trabalho de um procedimento inquisitivo, instaurado de ofício pelo juiz e movimentado sem ampla possibilidade de discussão da causa pelas partes. Ao contrário, trata-se de procedimento nitidamente contraditório, com ampla participação das partes, não sendo possível ao magistrado instaurá-lo de ofício. Não obstante, uma vez instaurado o processo pelas partes, a participação do Juiz do Trabalho na relação jurídica processual é mais ativa. (SCHIAVI, 2015, p. 138)
\end{abstract}

Enfim, para um processo democrático é essencial a participação das partes em atuação conjunta com o juízo, numa relação de coordenação, para que, assim, o direito fundamental à prova, inclusive, possa ser efetivado, com o magistrado conseguindo verificado, atendidas as especificidades do caso e das partes, a dificuldade para cada uma, da aptidão para a prova, sempre embasadas pelos princípios constitucionais da ampla defesa e do contraditório. O processo trabalhista passa, assim, a oportunizar um debate para uma solução efetiva, com viés realmente democrático.

\title{
CONSIDERAÇÕES FINAIS
}

A prova constitui-se como o sustentáculo dos processos judiciais, e, na esfera trabalhista seu papel é realçado, dada a principiologia que tem a busca da verdade real como basilar.

Nesse sentido, o ônus da prova deve ser interpretado diante da conjugação das especificidades laborais, e reconhecida a disparidade de forças na formação das provas, e, portanto, no espectro do Estado Democrático de Direito, com a participação efetiva das partes na formação do processo, junto ao juiz, a aplicação dinâmica do ônus da prova, analisada a aptidão e possibilidade é essencial. 
Há o reconhecimento da aplicação subsidiária e supletiva do Direito Processual Civil na seara trabalhista, e, inclusive, pode-se verificar um entrelaçamento entre os ramos processuais com um influenciando a legislação do outro, como ocorre no ônus probatório trazido pelo CPC de 2015, que levou à modificação do art. 818 da CLT, através da lei 13.467, que superou o dever de prova meramente pela alegação, ou seja, quem alegava tinha que provar, e, com a influência da processualística civil, passou-se a averiguar se há uma impossibilidade ou esforço excessivo de uma das partes. Denota-se, assim, que ao oportunizar o direito de prova, reconhecendo as fragilidades das partes, atende-se ao direito fundamental de provar uma proposição no processo para satisfação de um direito e para exercício da própria liberdade. Especialmente na seara trabalhista, essa possibilidade consagra a efetividade do processo, dada a disparidade de forças que pode então ser reconhecida pelo juízo.

Busca-se, ainda o atendimento dos rumos constitucionais, com a superação da conduta autocrática e solipsista do magistrado, sob a base democrática, que requer o diálogo e debate dos envolvidos, e, como reconhecido no Novo Código de Processo Civil, diante desse debate, dessa oportunização de diálogo entre as partes e o juiz, é possível vislumbrar, além dos casos previstos em lei, ou diante de peculiaridades da causa, a impossibilidade ou dificuldade excessiva a uma das partes para provar o alegado, tornando então possível a aplicação dinâmica do ônus da prova, e a possibilidade de reconhecimento de aptidão para o ônus da prova, para o alcance de uma decisão em conformidade com os parâmetros democráticos constitucionais, e que tem a verdade como ideal.

Assim, a aplicação subsidiária e supletiva do Direito Processual Civil no Direito Processual do Trabalho possibilitou o avanço do reconhecimento da possibilidade da inversão e da aptidão para a prova na seara trabalhista, destacando-se a essencialidade da prova para a formação do processo, e, ainda, consagrando tal direito como fundamental, destacada a previsão constitucional, haja vista a condução à efetividade dos direitos subjetivos com a efetiva participação das 
partes na formação do provimento judicial, além da oportunização de instrumentos de luta pela inclusão e justiça social.

\section{REFERÊNCIAS}

ALMEIDA, Cleber Lúcio de. Direito processual do trabalho. 5 ed., rev., ampl. e atual. Belo Horizonte: Del Rey, 2014.

Elementos da teoria geral da prova: a prova como direito humano e fundamental das partes no processo judicial. São Paulo: LTr, 2013.

BORGES, Leonardo Dias. O processo do trabalho à luz do novo Código de Processo Civil. Niterói, RJ: Impetus, 2014.

BRASIL. Lei no 13.105, de 16 de março de 2015. Código de Processo Civil. Diário Oficial da União, Brasília, DF, 17 de março de 2015.

. Lei no 13.467, de 13 de julho de 2017. Altera a Consolidação das Leis do Trabalho, aprovada pelo Decreto-Lei no 5.452, de 10 de maio de 1943, e as Leis nos 6.019 , de 3 de janeiro de 1974, 8.036, de 11 de maio de 1990, e 8.212, de 24 de julho de 1991, a fim de adequar a legislação às novas relações de trabalho. Diário Oficial da União, Brasília, DF, 14 de julho de 2017.

CAIRO JR., José. Curso de direito processual do trabalho. 5 ed. Salvador: Editora JusPodivm, 2012.

CASSAR, Vólia Bomfim. Direito do trabalho. 10 ed. Rio de Janeiro: Forense, 2014.

CRUZ, Clenderson. A ampla defesa na processualidade democrática. Rio de Janeiro: Lumen Juris, 2016.

DELGADO, Maurício Godinho. Curso de Direito do Trabalho. 15 ed. São Paulo: LTr, 2016.

DUARTE, Bento Herculano. Teoria da Prova no Novo CPC e sua incidência no Processo do Trabalho. In: SANTOS, Jackson Passos, MELLO, Simone Barbosa Martins. A aplicação do novo código de processo civil no processo do trabalho. São Paulo: LTr, 2016. p. 69-76.

EÇA, Vitor Salino de Moura; MAGALHÃES, Aline Carneiro (orgs.). Atuação principiológica no processo do trabalho: estudo em homenagem ao professor Carlos Henrique Bezerra Leite. Belo Horizonte: RTM, 2012. 
FAZZALARI, Elio. Instituições de direito processual. Campinas: Bookseller, 2006. GARCIA, Gustavo Filipe Barbosa. Curso de direito processual do trabalho. 6 ed. Rio de Janeiro: Forense, 2017.

LEITE, Carlos Henrique Bezerra. Curso de direito processual do trabalho. 15 ed. São Paulo: Saraiva, 2017.

LIMA, Leonardo Tibo Barbosa. Lições de direito processual do trabalho: teoria e prática. 4 ed. São Paulo: LTr, 2017.

PAMPLONA FILHO, Rodolfo; SOUZA, Tercio. Curso de direito processual do trabalho. São Paulo: Marcial Pons, 2013.

SCHIAVI, Mauro. Manual de direito processual do trabalho. 8 ed. São Paulo: LTr, 2015. 